\title{
Single-Stranded DNA-Binding Protein 2
}

National Cancer Institute

\section{Source}

National Cancer Institute. Single-Stranded DNA-Binding Protein 2. NCI Thesaurus. Code C101505.

Single-stranded DNA-binding protein 2 (361 aa, $\sim 38 \mathrm{kDa}$ ) is encoded by the human SSBP2 gene. This protein may be involved in genome stability. 